\title{
STUDIES ON NORTH AMERICAN CARBONIFEROUS INSECTS. 5. PALAEODICTYOPTERA AND MEGASECOPTERA FROM ILLINOIS AND TENNESSEE, WITH A DISCUSSION OF THE ORDER SYPHAROPTEROIDEA.*
}

\author{
By F. M. Carpenter \\ Harvard University
}

The insects treated in this paper are from the Upper Carboniferous deposits of the "Mazon Creek" region of Illinois and of a new locality in Anderson County, Tennessee. All represent undescribed species, with one exception - the type specimen of Sypharoptera pneuma Handlirsch, for which the author erected a separate order, Sypharopteroidea.

I am indebted to Dr. Sergius Mamay of the U. S. Geological Survey and to Mr. Robert Rapp for the opportunity of studying the Tennessee fossil; and to the authorities of the Peabody Museum at Yale University for the loan of the type of the Sypharoptera. To Mr. Walter Dabasinskas of Cicero, Illinois, I am especially grateful for his kindness in sending me for study more of the remarkable insects which he has collected in the ironstone nodules near Braidwood, Illinois. The efforts which he and Mrs. Dabasinskas have put into the collecting of fossils in the nodules are a major contribution to the study of Carboniferous insects.

\section{Order Palaeodictyoptera}

Family Breyeriidae Handlirsch

This family includes species of large size, having an unbranched $\mathrm{MA}$ and $\mathrm{CuA}$, a forked $\mathrm{CuP}, \mathrm{MP}$ with at least three branches and Rs with at least four branches; cross veins are numerous and somewhat irregular but do not form a reticulation. The hind wings are broader basally than the fore wings but the venation is essentially the same except for the more numerous anal veins.

The family has been found in Upper Carboniferous strata in England, Belgium, France and Czechoslovakia. ${ }^{1}$ The species described below is the first from a North American deposit. The generic

\footnotetext{
*This research has been aided by Grant No. GB 2038 from the National Science Foundation. The previous part in this series was published in Psyche 72: 175-190. 1965.
} 
classification of the Breyeriidae has been reviewed by Kukalová (1959); there now seem to be only two valid genera, Breyeria Borre and Strobbsia Handlirsch. The latter is known from the Upper Carboniferous of England but Breyeria is represented in the other European deposits mentioned under the family and is the genus to which the North American species belongs.

\section{Genus Breyeria Borre}

Breyeria Borre, C. R. Soc. Ent. Belg., 1875 : 7 ; synonyms : Borrea Brongniart, 1893; Megaptiloides Handlirsch, 1906; Pseudoborrea Handlirsch, 1919; Breyeriopsis Laurentiaux, 1949.

\section{Breyeria rappi, new species}

Plate 8; text-figure I

Fore wing: length $8 \mathrm{I} \mathrm{mm}$.; width $25 \mathrm{~mm}$. Costal margin smoothly curved; costal space with a short longitudinal vein basally; costal space not broadened basally; Sc terminating on RI just beyond the first fork of Rs; RI extending to the very apex of the wing; $R$ arising at the level of the fork of $M$, with six terminal branches; MP with three terminal branches; cross veins mostly straight, a very few branched in the area between Rs and MA; small circular, cuticular thickenings occur between some of the branches of Rs, between Rs and MA, and between MA and MP.

Holotype: No. I 58550, U.S.N.M., Washington, D.C.; collected by Mr. Robert Rapp in the "Pewee" Coal Seam at a strip mine near Peach Tree Gap, Anderson Country, Tennessee. The specimen (Plate 8) consists of a virtually complete wing, lacking only a few millimeters of the apex, and it is perfectly preserved. The species is named for Mr. Rapp. Dr. Mamay has informed me (pers. com.) that, on the basis of the fossil plants which Mr. Rapp collected in the Pewee Coal Seam, he considers the deposit to be of Lower or Middle Allegheny age. This would correspond closely to the Westphalian C Stage of the European Upper Carboniferous.

This species differs from others in Breyeria by a series of minor (but presumably specific) characters, such as the general shape of the wing, the number and arrangement of branches of Rs and the pattern of cross veins. The fossil shows no sign of color markings,

\footnotetext{
${ }^{1}$ The fossil which Keller (1935) described as Breyeria constantini from the Upper Carboniferous of the Ruhr Valley in Germany is so fragmentary that its assignment to any family is problematical.
} 


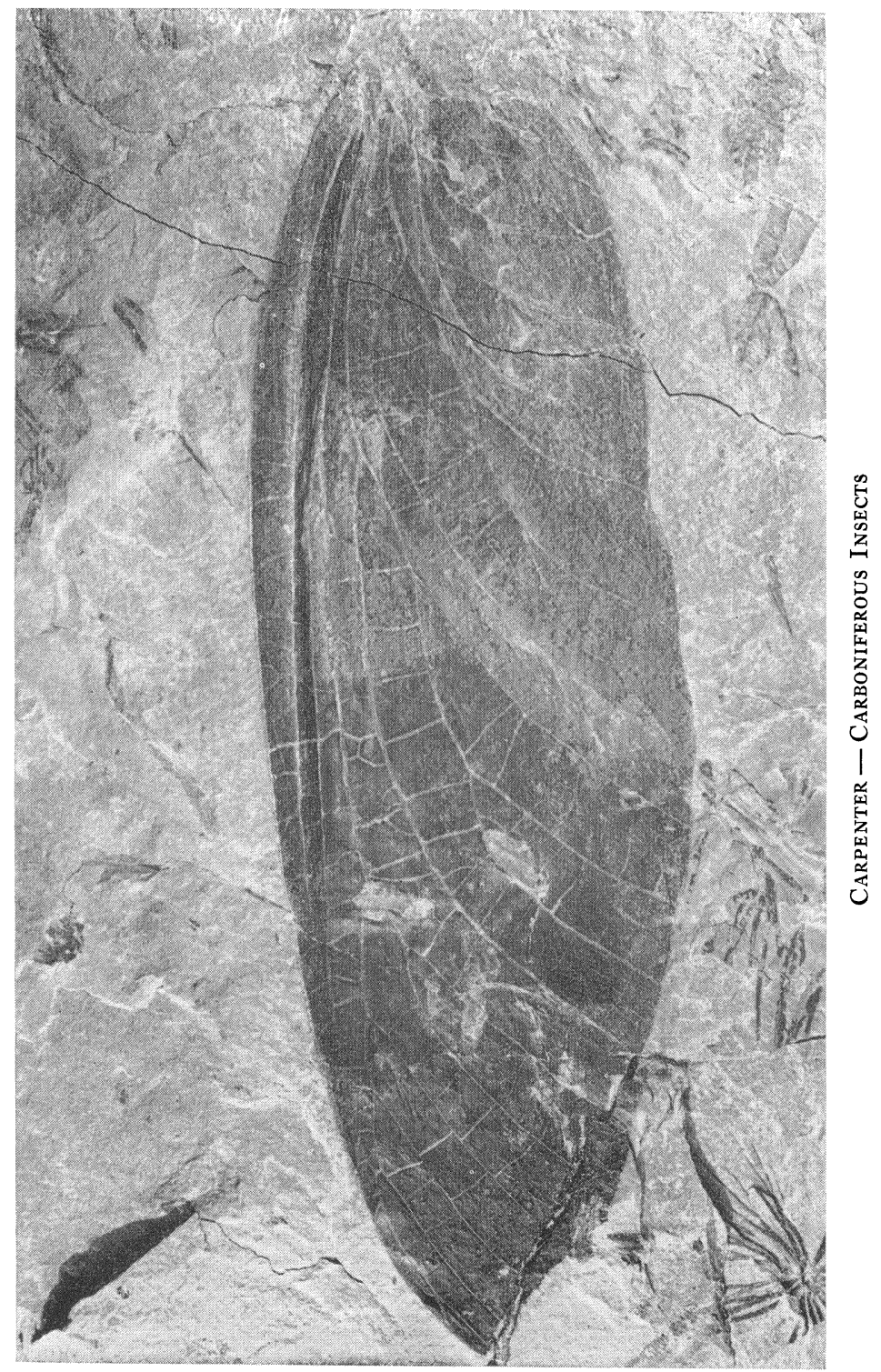


as had been noted by Laurentiaux-Vieira and Laurentiaux (1964) in Breyeria vrankeni from the Upper Carboniferous of Holland. ${ }^{2}$ It is most interesting and unexpected to find a representative of the

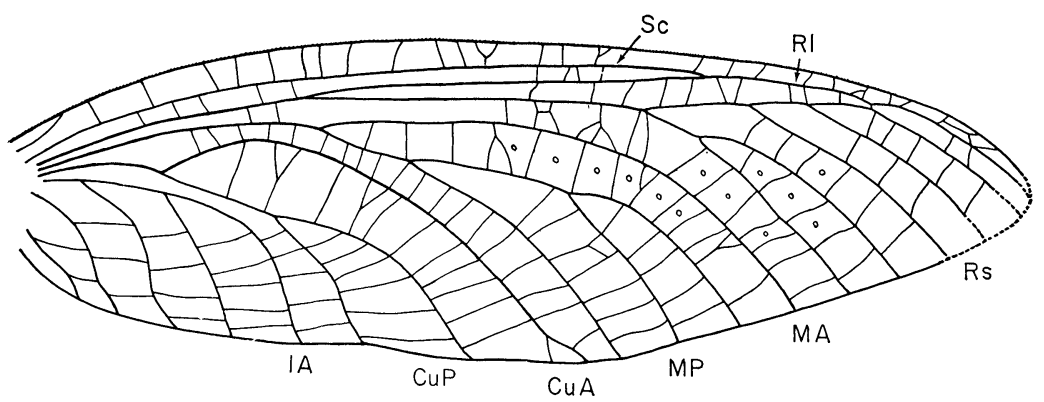

Text-fig. 1. Wing of Breyeria rappi, n. sp. (holotype)

family Breyeriidae in the Upper Carboniferous strata of the New World, especially since the fossil shows no differences which separate it generically from the European species. Indeed, the uniformity of the venational pattern of the known Breyeriidae is very striking.

The excellence of the preservation of the type of $B$. rappi reveals some noteworthy features. One of these is the presence of a distinct but short longitudinal vein at the base of the costal space. This is undoubtedly comparable to the several ridges of veins that Kukalová (1960) and Carpenter (1964) have noted in other Palaeodictyoptera. It is by no means certain, however, that this vein is the costa or that a true pre-costal space exists, like that in the Protodonata. Laurentiaux has noted (1964) that he finds no sign of this basal vein in the costal area of the species which he studied.

Another interesting feature of the wing of $B . r a p p i$ is the presence of the small, circular, cuticular thickenings between several of the veins. These have been previously reported in the Breyeriidae by Laurentiaux-Vieira and Laurentiaux (1963, 1964). Similar platelike thickenings have been noted in some of the Protodonata (Bolton, 1914, Carpenter 1947) and somewhat larger plate-like thickenings

\footnotetext{
${ }^{2}$ The difference in color between the basal and distal parts of the wing of B. rappi, as shown in the photograph, is almost certainly due to peculiarities of preservation rather than to pigmentation in the wing of the living insect.
}

Explanation of Plate 8

Breyeria rappi, n. sp. Photograph of holotype. Upper Carboniferous of Tennessee. Length of wing, $81 \mathrm{~mm}$. 
occur in the Diaphanopterodea (Carpenter, 1963) and in some of the orthopteroids. There is no basis, however, for regarding these as nygmata, a term which was used by Navas for certain clear, cuticular spots on the wings of some Trichoptera, Neuroptera and related Endopterygota (see Carpenter, I963, p. 243, footnote).

\section{Family Fouqueidae Handlirsch, I906}

This family has previously been known only from the Upper Carboniferous shales of Commentry, France, in which it is represented by the genus Fouquea Brongniart and four species. The characteristics which seem to be peculiar to the family are the combination of a branched $\mathrm{CuA}$ and very numerous cross veins, which form a true reticulation only along the posterior portion of the wing. The branched $\mathrm{CuA}$, which is not found in the more primitive Palaeodictyoptera, is a characteristic of the Spilapteridae also, but the cross veins in that family are very few in number and are usually aligned to form gradate series.

Mr. Walter Dabasinskas of Cicero, Illinois, has recently sent me a specimen of a palaeodictyopteron which has the same combination of characteristics given above for the Fouqueidae. It cannot, however, be referred to the genus Fouquea and is therefore taken as the basis of the new genus described below.

\section{Genus Neofouquea, new genus}

Subcosta closer to $\mathrm{R}$ and $\mathrm{R}_{\mathrm{I}}$ than in Fouquea; CuA deeply forked, i.e., to about the same level as the fork of $M$ into MA and MP; $\mathrm{CuA}$ dichotomously branched; $\mathrm{CuP}$ deeply forked, without additional branches. Wings with two slightly curved rows of maculations in the basal half; additional maculations probably present in the more distal part of the wing.

Type-species: Neofouquea suzanneae, n. sp.

In contrast to this genus, Fouquea has a pectinately branched $\mathrm{CuA}$ and a multiple branched $\mathrm{CuP}, \mathrm{CuPr}$ having three or four terminal branches. The cross veins in Neofouquea seem as close together as they are in the other known species of the family Fouqueidae.

\section{Explanation of Plate 9}

Neofouquea suzanneae, n. sp. Photograph of holotype. Upper Carbonirerous of Illinois. 


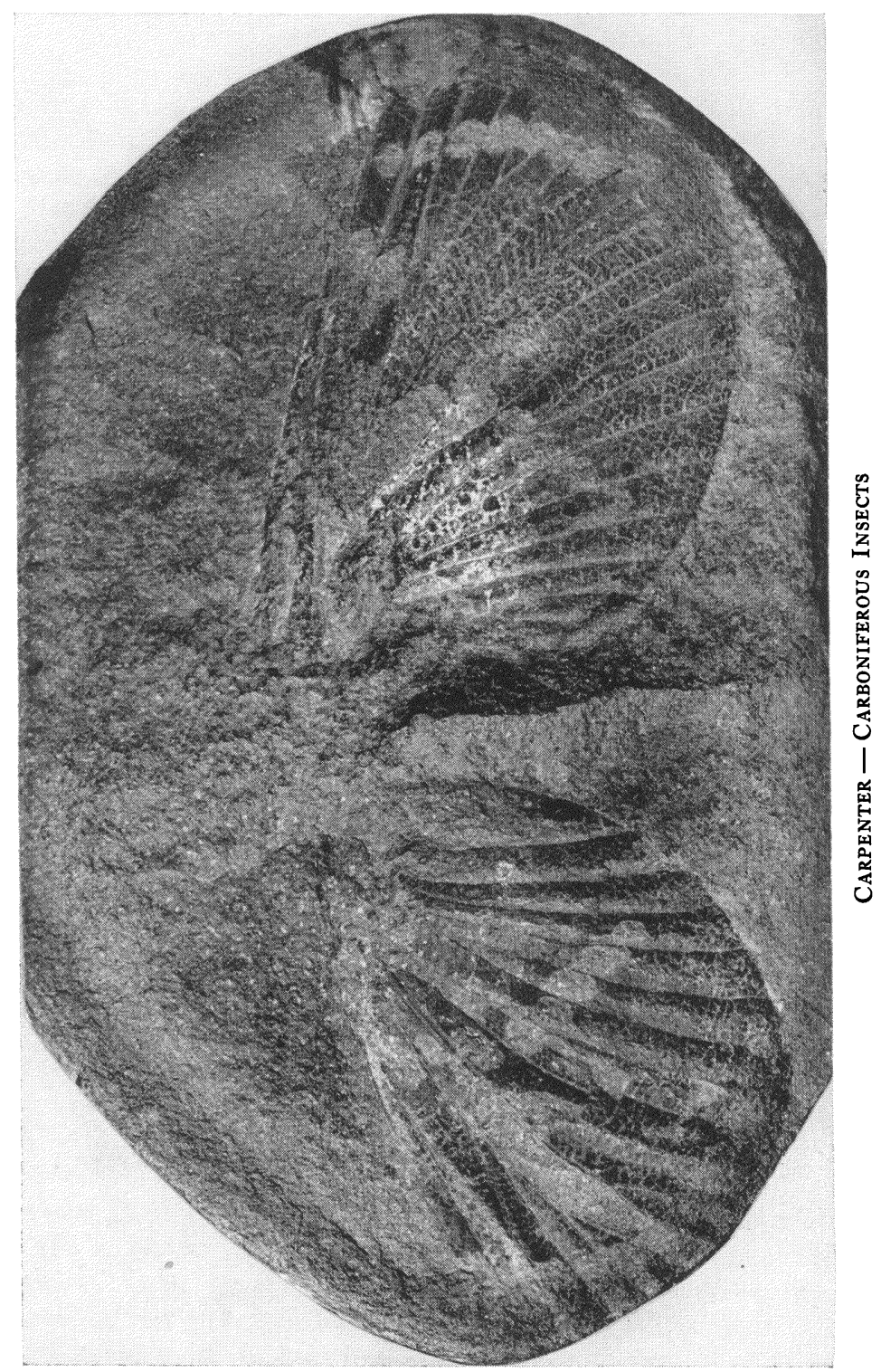


Neofouquea suzanneae, new species

Plate 9; text-figure 2

Length of wing as preserved, $30 \mathrm{~mm}$., maximum width, $22 \mathrm{~mm}$.; estimated length of entire wing, based on comparison with species of Fouquea, 65-70 mm. Since only the basal half of the wing, is preserved, the forking of Rs and of MA is unknown, but both of these veins arise much as in the species of Fouquea; MP forks shortly after its origin, MPI being without a branch in the preserved portion of the wing, but $\mathrm{MP}_{2}$ is dichotomously forked at about the level of the outer row of maculations; $\mathrm{CuA}$ divides at about the level of the first division of $\mathrm{M}$, much as in Fouquea; $\mathrm{CuAI}_{\mathrm{I}}$ and $\mathrm{CuA}_{2}$ are forked to about the same level; $\mathrm{CuP}$ is deeply forked, producing a nearly straight $\mathrm{CuPI}$ and a somewhat sigmoidally curved $\mathrm{CuP}_{2}$, as in the other Fouqueidae; the two branches of $\mathrm{CuP}$

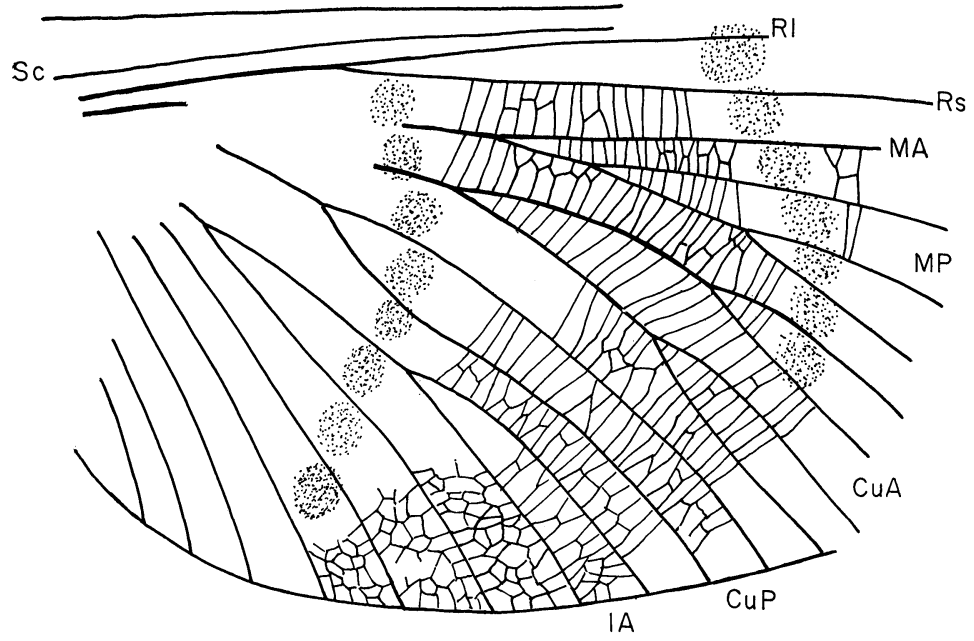

Text-fig. 2. Wing of Neofouquea suzanneae, n. sp. (holotype).

are close together, without secondary branches; the first two anal veins arise from a single stem and the anterior one is forked but not so deeply as in Fouquea. Several anal veins appear to radiate from a basal stem, although their proximal portions are not preserved. The cross veins form an irregular reticulation in the distal portions of the anal veins and along the posterior border of the wing near $\mathrm{CuP}$; in other regions the cross veins are nearly parallel, very close together and only infrequently have connecting branches. An inner 
row of maculations, consisting of irregularly circular spots, occurs at about the level of the origin of $\mathrm{Rs}$ and just beyond the fork of $\mathrm{CuP}$; the more distal row occurs just beyond the level of the fork of $\mathrm{MP}_{2}$ and $\mathrm{CuA}_{\mathrm{I}}$; there are apparently eight spots in each of the rows.

The type specimen, which is in the collection of Mr. Dabasinskas, Cicero, Illinois, consists of basal portions of two wings (see Plate 9). The main veins and the cross veins are well preserved and the maculations are clear. The species is named for Suzanne Dabasinskas, in recognition of the persistence and patience which she, as well as her husband, Walter Dabasinskas, have shown in their collecting of the Mazon Creek insects. The specimen of N. suzanneae was collected between Braidwood and Coal City Illinois (Will Co.).

Since no satisfactory figure of Fouquea lacroixi Brongniart (the type species of the genus) has previously been published, I include here a drawing of the venational pattern of the type based upon study of the fossil at the Institut de Paleontologie in Paris. A comparison of the venation of lacroixi with that of suzanneae indicates that the type specimen of the latter consists of the basal half of the wing, not quite as far distally as the first branch of the radial sector or of the fork of MA. The greater width of the wing of the specimen of suzanneae and the curvature of $\mathrm{CuA}$ suggest that the specimen is part of a hind wing, not a fore wing; however, since no complete specimen of the family Fouqueidae has been found, we do not have certain knowledge of the difference between the front and the hind wings.

The densely arranged cross veins, which are clearly indicated in the type of suzanneae, are similar to those of the several species of Fouquea in the Commentry shales. They are present in the type of lacroixi, although they were not represented in Brongniart's figure of the fossil. They are, however, especially clear over the entire wing of the type of $F$. superba (Meunier), as shown in the accompanying photograph (Plate Io)..$^{3}$

The specimen of Fouquea lacroixi shows prominent maculations on the wings, arranged in irregular rows, as depicted in Brongniart's figure (I893, plate I9, fig. IO). Specimens of the other species of Fouquea [i.e., comstocki Lameere, needhami Lameere, superba (Meu-

\footnotetext{
${ }^{3}$ The genus Archaecompsoneura, which was established for superba (Meunier, 1909), is a synonym of Fouquea, as noted by Lameere (1917), although this is not apparent from Meunier's grossly inaccurate figures $(1910,1912)$.
} 


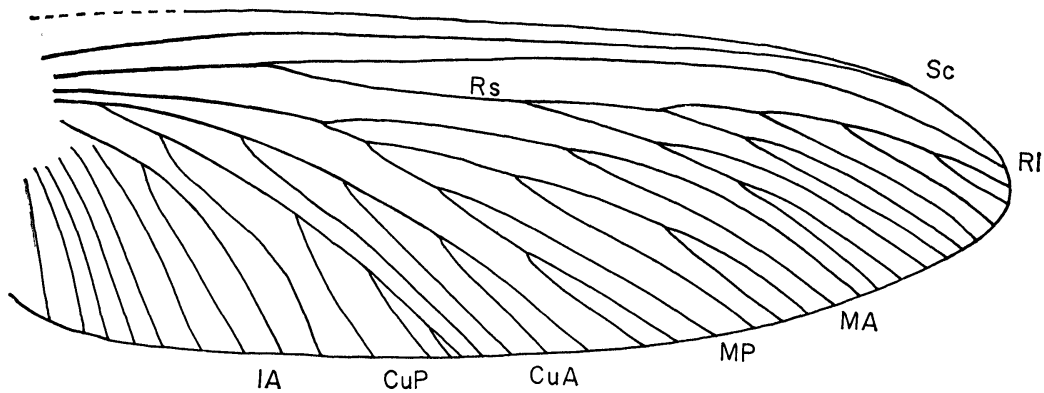

Text-fig. 3. Wing of Fouquea lacroixi Brongniart; original drawing based on type specimen in Institut de Paléontologie, Paris. Upper Carboniferous of Commentry, France.

nier)] show similar patterns. The maculations on the wings of suzannaea are much smaller and are arranged in definite rows, as shown in the photograph, Plate 9.

The only palaeodictyopteron described from the ironstone nodules of Illinois that resembles $N$. suzanneae is Diexodes debilis Handlirsch (I9II), which was based on a small, poorly preserved wing fragment. However, the cross veins in debilis (the type of which I have examined at the Peabody Museum) are relatively few in number and do not, therefore, form the dense pattern characteristic of the Fouqueidae.

\section{Order Megasecoptera}

\section{Family Brodiidae Handlirsch, I906}

This family was established by Handlirsch for a single species, Brodia priscotincta Scudder from Upper Carboniferous deposits in England. From the time of its description in $\mathrm{I} 88 \mathrm{I}$, this species has presented numerous problems with respect to both the nature of the structures preserved and their phylogenetic interpretation. Although numerous specimens (at least 15) have been subsequently found, these have consisted only of isolated wings or fragments of wings; nothing is known, therefore, of the differences between the fore and hind wings or of the body structure. The relationships of Brodia have been uncertain. Handlirsch placed the family at first in the

\section{Explanation of Plate 10}

Fouquea superba (Meunier). Photograph of holotype, showing pattern of cross veins characteristic of Fouqueidae. Length of wing, $50 \mathrm{~mm}$. 


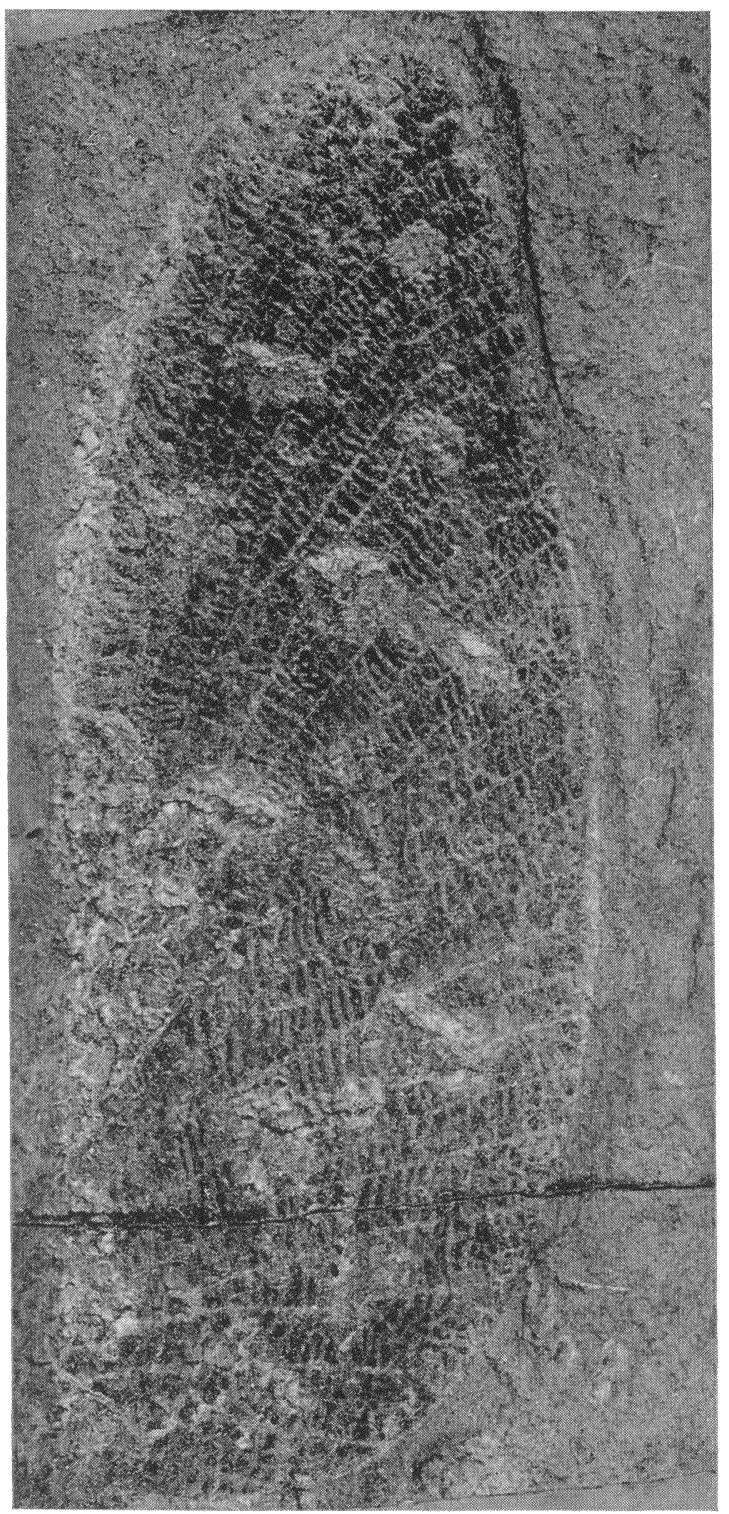


Palaeodictyoptera (1906) but subsequently (1919) transferred it to the Megasecoptera. This position has been the one generally accepted, although Bolton (I92I) retained it in the Palaeodictyoptera.

One of the specimens recently sent to me by Mr. Walter Dabasinskas is a remarkably well preserved wing obviously belonging to the family Brodiidae and close to Brodia, but clearly requiring a new genus. The excellent preservation of this fossil has answered some of the questions which have been raised for many years about the Brodiidae. Before describing this new specimen and discussing its affinities, it is necessary to redefine the family Brodiidae on the basis of this additional record and the specimens of Brodia priscotincta which I have examined in the British Museum, the U.S. National Museum, and especially in the Scudder collection at the Museum of Comparative Zoology.

The Brodiidae as now known possessed petiolate wings. The costal vein was distinctly serrate on both its anterior and posterior borders; the serrations also extend along the posterior border of the wing, although in general they are smaller and more widely spaced; in some the serrations along the posterior border of the petiole form stout setae; Sc is close to R basally and parellels RI for most of its length; it apparently merges with the costa somewhat beyond midwing but retains its identity until near the apex of the wing (see plate I4); R and Ri are nearly straight until near mid-wing, beyond which $\mathrm{RI}_{\mathrm{I}}$, which is unbranched, curves slightly away from the costal margin; Rs arises well before mid-wing and forms three or four branches; $M$ arises as an independent vein at the base of the wing, curving slightly posteriorly and forking to produce MA; MA is unbranched and diverges anteriorly towards the origin of Rs, which it very nearly touches; MP divides shortly after the level of the origin of $\mathrm{Rs}$, producing at least two terminal branches; $\mathrm{Cu}$ arises as an independent vein at the base of the wing, soon dividing into $\mathrm{Cu} A_{2}$, which curves slightly anteriorly towards $\mathrm{M}$ before turning toward the posterior margin; it is without branches; $\mathrm{CuP}$ terminates slightly beyond the origin of Rs. I anal vein only is present, this terminating on the posterior margin close to the base of the wing at about the level of the origin of MA. A fine archedictyon may be present over much of the wing surface but true cross veins, sometimes irregular and sometimes nearly straight, occur on certain parts of the wing. Differences in the shape of the fore and hind wings are unknown and the body structure is also unknown.

The family is now represented by two genera: Brodia, from the 
Upper Carboniferous of England, and Eubrodia, new genus, from the Upper Carboniferous of Illinois.

\section{Genus Brodia Scudder}

Brodia Scudder, 1881, Geol. Mag. 8 : 293.

Wings slender, broadest at about the level of mid-wing; cross veins of two types, a few distinct ones mostly in two irregular series, and an almost uniform pattern of very weak transverse cross veins, very close together, but not forming an archedictyon or a reticulation.

Type-species: Brodia priscotincta Scudder Brodia priscotincta Scudder

Plate II and text-fig. $4 \mathrm{~A}$

Brodia priscotincta Scudder, 1881, Geol. Mag. 8: 293; Scudder 1883, Mem. Bost. Soc. Nat. Hist. 3: 213, pl. 17; Scudder, 1885, in Zittel, Handbuch der Palaeontologie, 2: 761, fig. 951; Handlirsch, 1906, Foss. Ins., p. 113, pl. 12, fig. 13; Handlirsch, 1919, Denkschr. Akad. Wissensch. Wien, Math.-Naturw. Klasse, 96: 73-75, figs. 83-89; Bolton, 1921, Foss. Ins. Brit. Coal Meas., 1: 59-63, figs; Laurentiaux, 1953, in Piveteau, Traité de Paléontologie, 3 : 543, fig. 39.

Synonyms: Brodia scudderi Handlirsch, B. petiolata Handlirsch, B. pictipennis, $B$. fasciata Handlirsch, $B$. nebulosa Handlirsch, and $B$. furcata Handlirsch (all Handlirsch 1919).

Wing: length 50-58 mm., maximum width, I3-15 mm. Rs with four or five branches; MP usually with two branches, rarely three; a few distinct cross veins in certain areas of the wing, usually transverse or slightly oblique but not reticulate. Wing with three distinct dark transverse bands and a darkened area between $\mathrm{RI}_{\mathrm{I}}$ and Rs. Type: British Museum (Natural History), Brodie collection No. I.3896. Bolton recorded eleven specimens of priscotincta in the British Museum and in the collection at Birmingham University; all of these were from Coseley, Tipton, Sedgeley, or Dudley, Staffordshire, England. Upper Carboniferous (Westphalian).

Several features of this insect, briefly mentioned under the genus and family, require more detailed discussion:

(I) The wing shape. Although Scudder's original figure (I88I) of this insect showed a distinct petiolation on the wing, the figure which he published in his more detailed account a few years later ( 1883 ) shows much less petiolation and the figure he used in Zittel's Handbuch ( 1885 ) shows no petiolation whatsoever. Since all three figures were made from the holotype specimen, we can only conclude that Scudder was not certain of the correct interpretation of the margins of the wing in the specimen. Only a few of the specimens in the British Museum collection show the basal portion of the wing, 

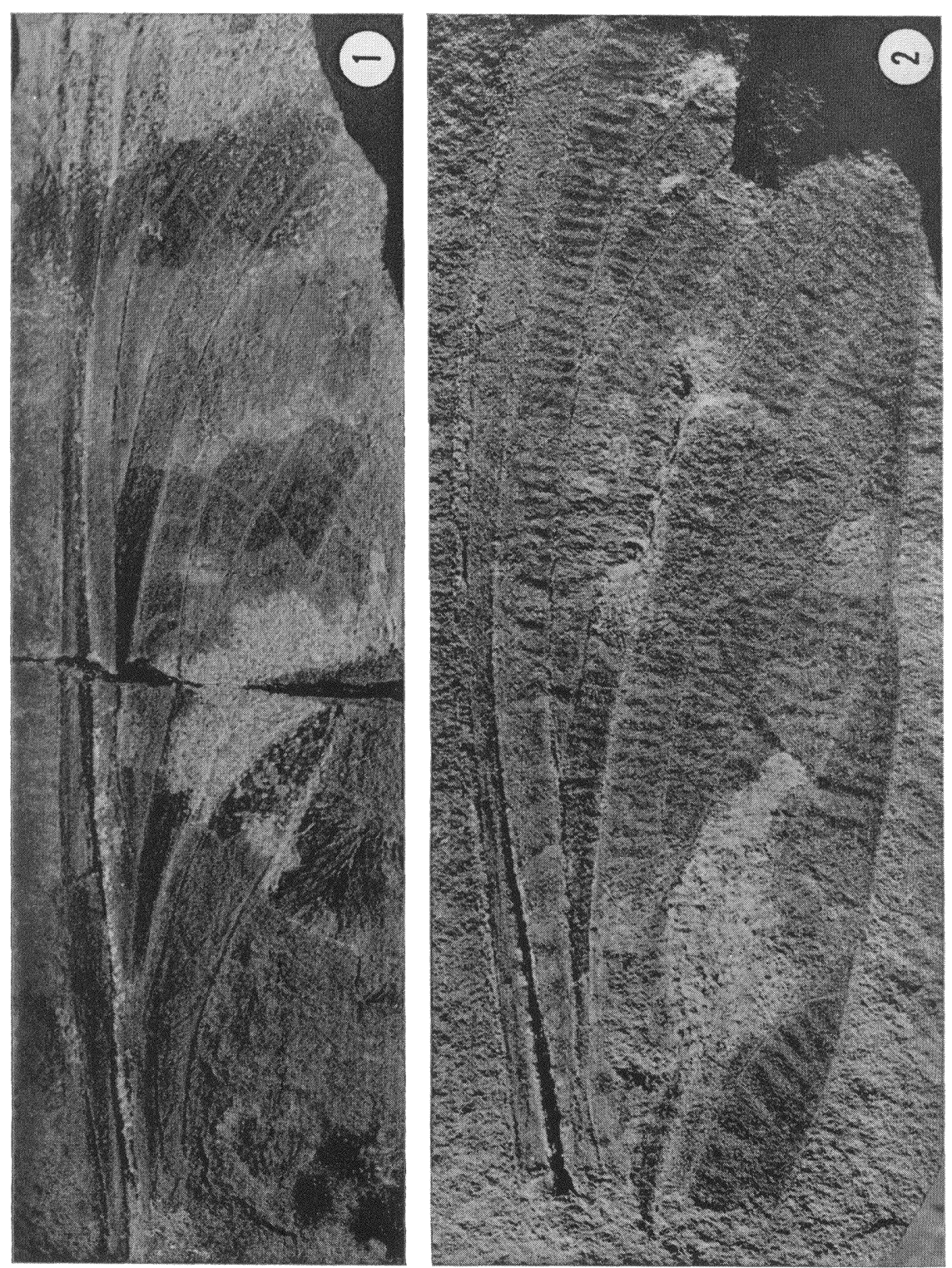
but in all of these the wing base is distinctly petiolate, as shown in Handlirsch's figures (1919). In his diagrammatic representation of the wing, Bolton (I92I) shows a subpetiolate condition, in which the wing narrows rather more gradually than depicted in Handlirsch's figures. Although there is probably some slight variation in the degree of petiolation of the wing, I believe that Handlirsch's figures are more nearly correct in respect to this part of the insect. One of the two specimens in the Scudder collection at the Museum of Comparative Zoology shows the petiole distinctly (Plate II). It is possible, of course, that the fore and hind wings differed in the degree of

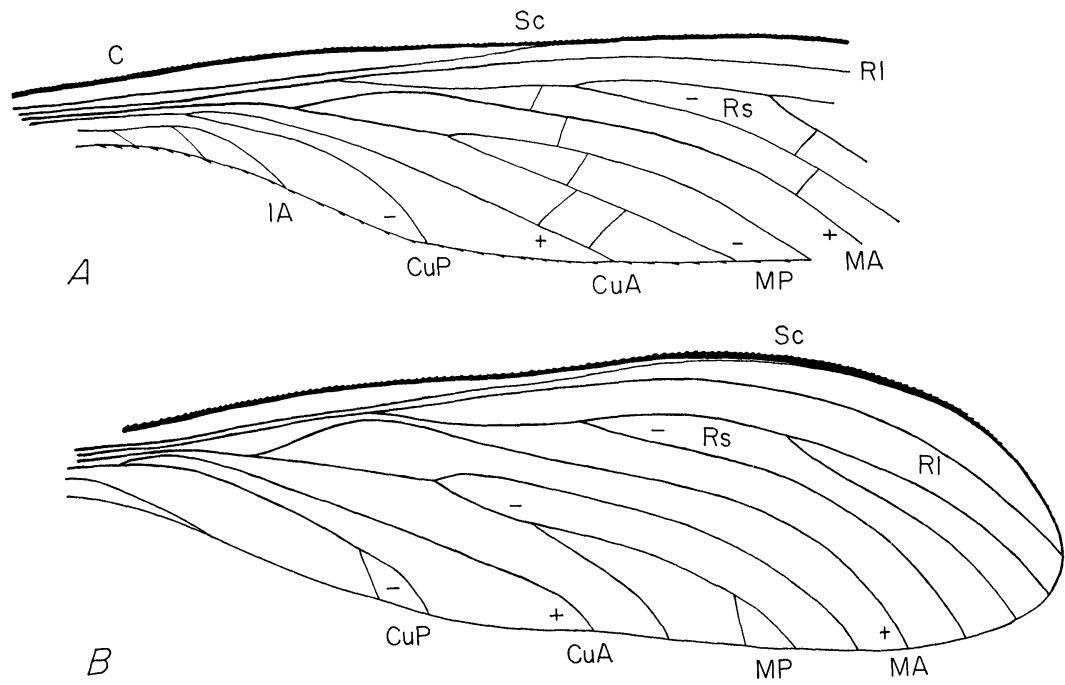

Text-fig. 4. Comparison of wings of Brodia and Eubrodia. A, Brodia priscotincta Scudder. Drawing of wing, based on specimens in Scudder Collection, M.C.Z. B, Eubrodia dabasinskasi, n. sp. Drawing of wing, based on holotype. The cross-veins and archedictyon are omitted; for these, see plates 12 and 13.

Explanation of Plate 11

Brodia priscotincta Scudder. Upper Carboniferous of England.

Fig.1. Photograph of specimen no. 5842 in M.C.Z. (Scudder Collection), showing the petiole and the transverse, dark bands on the wing. Actual length of wing as preserved, $55 \mathrm{~mm}$.

Fig. 2. Photograph of specimen no. 5843 in M.C.Z. (Scudder Collection), showing the dense pattern of fine cross veins; photographed under very oblique light. Actual length of wing, as preserved, $36 \mathrm{~mm}$. 
petiolation but of this we have no information. Bolton figured and described the costal margin at the level of the middle of the petiole as having a distinct hump-like elevation but I have not seen this in any of the specimens which I have examined. There is some uncertainty about the shape of the apex of the wing. Curiously enough, this is missing in all specimens of the species which have been individually described; none of those which were described and figured by Handlirsch and by Bolton show the apex; Bolton includes the apex in his diagrammatic figure of the complete wing but he does not indicate the specimen on which the drawing was based. However, the shape of the wing apex as shown in his "complete wing" is more broadly rounded than that in any specimens which I have seen or which have been described by Handlirsch. The wing represented by Laurentiaux (1953) in an original drawing based upon specimens in the Birmingham Museum has a much more bluntly rounded apex; however, his entire figure seems to be somewhat diagrammatic and is probably not intended to represent the precise form of the wing. The absence of the apical part of the wing in so many specimens suggests that the wings of Brodia were unusually fragile and delicate.

(2) The serration of the wing margins. The serrate margin is one of the more obvious features of Brodia and it has been figured or mentioned in virtually all accounts of this species. The description and especially the figure given by Scudder in 1883 are accurate and detailed. The structure of the costa is very clearly preserved in the specimens in the M.C.Z. (Scudder collection); they show that the costa has the serrations along both its anterior and posterior edges, those of the anterior edge being somewhat sharper. Beyond the point where the subcosta joins the costa the serrations along the posterior margin of the costa become more pronounced, as correctly drawn by Scudder (see top fig., Plate I4). The subcosta, which is not actually fused or united with the costa, remains visible as an independent vein. In one of the specimens in the Scudder collection the costal margin is very clearly preserved and shows also in the distal part serrations or short spines on the subcosta in that region, making a total three rows of these short projections. ${ }^{4}$ It is to be noted in this connection that the radius also bears a few setal bases (see Plate I4). The serrations become very small along the posterior margin distally

\footnotetext{
${ }^{4}$ The costal structure of Brodia resembles to a striking degree that of the anisopterous Odonata, in which the costa also has serrations on both the anterior and posterior borders.
} 
but the basal part of the hind margin has a few well-developed serrations or heavy stout spines, projecting apically.

(3) The cross veins. These have been the source of considerable confusion. Several distinct cross veins in the pigmented area of the wings have been represented in the drawings of virtually all previous accounts. They appear to be absent from the light or hyaline areas of the wings but I suspect that this is due to the failure of the cross veins to show up in a hyaline area. Bolton was of the opinion, however, that the wing did not, in fact, have color-bands and that the light areas were the result of the wing membrane's being destroyed in those areas. However, the uniformity of the pattern of these dark and light areas in the dozen specimens which have now been found refutes Bolton's theory; furthermore, the presence of the very fine cross veins on the light areas shows that the wing membrane is actually preserved there. The fine indistinct cross veins were noted by Scudder ( 1883 , p. 236) as being "transverse to the nervures they connect, pretty regularly and uniformly distributed over the wing", and Handlirsch (1919) represents them in a few of his figures, although they were not mentioned by Bolton (192I). The effect of these numerous, fine transverse veins is to produce a wrinkled appearance on the wing membrane (see figure 2, plate II). They are of special significance in view of the presence of a distinct archedictyon in Eubrodia; it is my belief that these are vestiges of the archedictyon which are in the process of being lost and replaced by heavier cross veins.

\section{Eubrodia, new genus}

Wing: almost certainly petiolate, as in Brodia, but broadest beyond the middle; pattern of main veins much as in Brodia; no prominent cross veins as in Brodia; a fine archedictyon developed over most areas of the wing; in areas just basal and proximal to the midwing the archedictyon is absent, the cross veins forming a course reticulation.

Type-species: Eubrodia dabasinskasi, n. sp.

\section{Eubrodia dabasinskasi, n. sp.}

Plates 12 and 13 ; text-figs. $4 \mathrm{~B}$

Wing length as preserved, $48 \mathrm{~mm}$., maximum width, $15 \mathrm{~mm}$.; estimated length of complete wing, $55 \mathrm{~mm}$. The costal margin is slightly concave at about mid-wing, the pterostigmal area being 


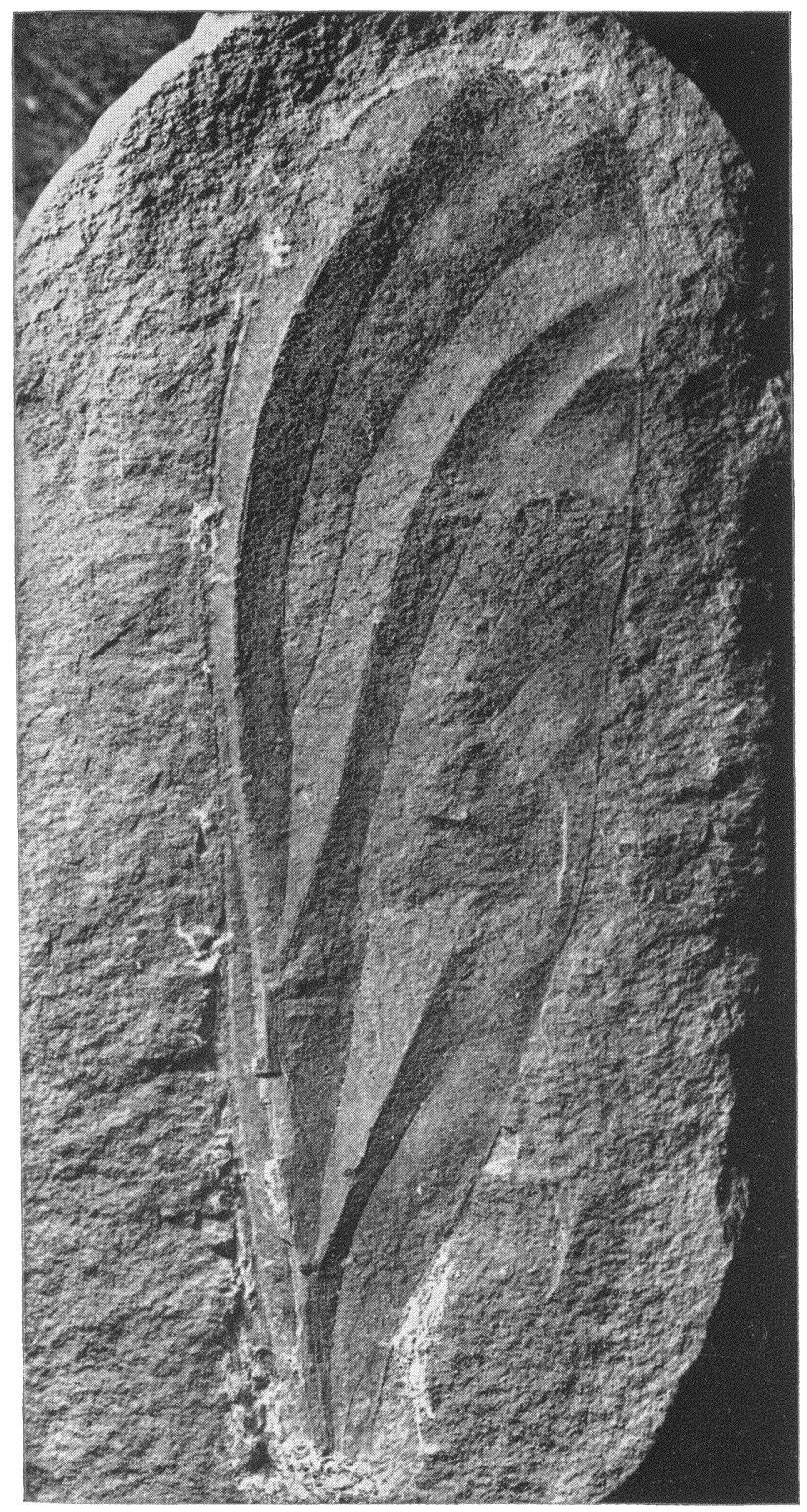

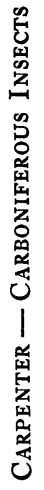


noticeably convex; apex of wing posterior to the wing axis; Rs with three terminal branches; MP also with three but with one additional terminal twig on $\mathrm{MP}_{3}$ (probably an individual variation); $\mathrm{CuP}$ also with a terminal twig. There is a slight, subtle indication of the presence of two light bands across the wing, one just basal of the mid-wing and the other just beyond the mid-wing, these being in about the same position as the light areas in Brodia priscotincta. The details of the venational pattern of the cross veins are shown in plate 13.

Holotype: In the collection of Mr. Walter Dabasinskas, Cicero, Illinois, collected at Pit No. I I, Peabody Coal Company, Section Four, Braidwood, Illinois. The type specimen consists of a virtually complete wing, lacking only the proximal part of the petiole. The preservation is better than that of any other specimen of Brodiidae that I have seen. The species is named for Mr. Dabasinskas in recognition of his efforts and success in collecting insects in the ironstone nodules.

The similarity of the wing of $E$. dabasinskasi to that of $B$. priscotincta is very striking. The obvious differences are in the shape of the wings and in the nature of the cross veins. Additional comments about these and other characteristics of dabasinskasi follow.

( I) The wing shape. Comparison of the venational pattern of dabasinskasi and priscotincta indicates strongly that the wing of dabasinskasi was actually petiolate, the petiole being absent in the fossil. The position of $\mathrm{IA}$ and of the point of separation of $\mathrm{CuA}$ and $\mathrm{CuP}$ in dabasinskasi suggests that the wing extended for about the same length as the petiole does in priscotincta. Apart from the basal portion, the wing of dabasinskasi is noticeably broader distally than that of priscotincta. Its shape is very close to that of the supposed nymphal forms of Brodia which Bolton described (1921, fig. I6 \& I7). As a matter of fact, the shape of the wing of priscotincta as shown in Bolton's drawing (figure I5) is much more like that of dabasinskasi than it is like the actual specimens of priscotincta. ${ }^{5}$

\footnotetext{
${ }^{5}$ The nymphal wings which Handlirsch described as Lameereites curvipennis from the Mazon Creek nodules (1911, p. 375) resemble in general form the nymphal wings described by Bolton as belonging to Brodia. There is a good chance that the nymphal Lameereites belongs to the family Brodiidae but there is no certainty of it and even less probability that the nymph is the immature form of Eubrodia.
}

Explanation of Plate 12

Eubrodia dabasinskasi, n. sp. Photograph of holotype. Length of wing, as preserved, $48 \mathrm{~mm}$. 


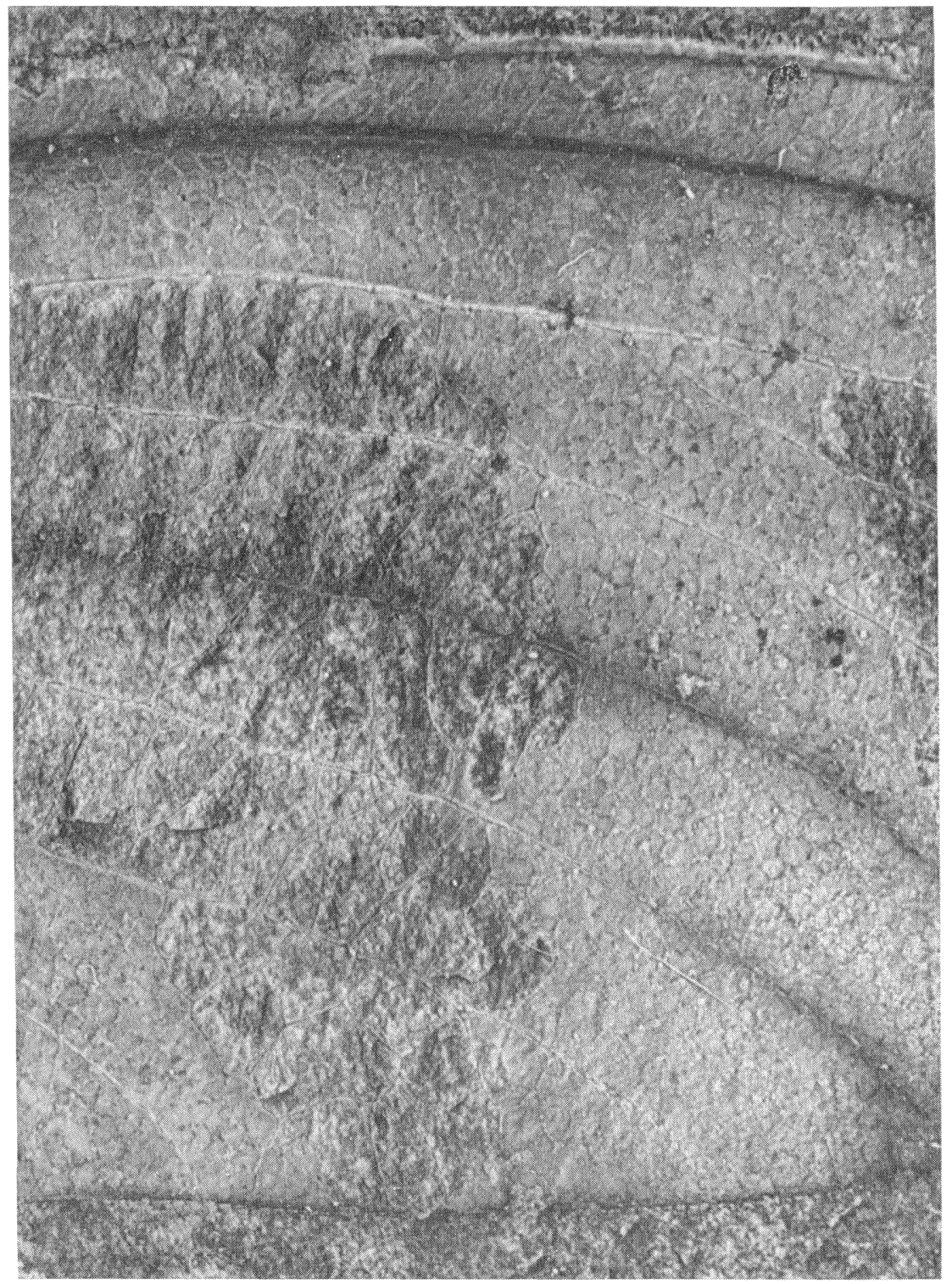

CARPENTER - CARboniferous Insects 
(2) Serrations of the wing margin. These are essentially the same as in Brodia but in the pterostigmal region of the wing, the costa is somewhat broadened and the serrations or macrotrichia are larger and more numerous. The subcosta can be seen to continue along the costa towards the apex of the wing and it also bears the short setal processes in the pterostigmal area. (See photograph, bottom fig. plate 14). The radius bears occasional setal bases as in Brodia itself. There do not appear to be any heavy setae along the posterior margin, even on the margin near IA. In this connection it is interesting to note the similarity between the costal margin of Brodia and Eubrodia and that of Anchineura, a megasecopteron from the Upper Carboniferous of Spain (Carpenter, 1963).

(3) The cross veins and archedictyon. These constitute the most distinctive features of Eubrodia; the presence of an archedictyon in the Brodiidae is totally unexpected. The archedictyon in Eubrodia is a very regular one, present over most of the wing; the individual cells are almost hexagonal in form. In the costal area there are distinctly differentiated transverse veinlets and in the two regions of the wing just basal to the mid-wing and just distal to the midwing, the cross veins form a very different pattern. (See Plate 13). One gets the impression from the structure of the cross veins in Eubrodia that the archedictyon is in the process of developing into a more regular and more open reticulation. It now seems probable. from the structure of the wing membrane in Eubrodia, that the fine transverse lines in Brodia, shown in the photograph (figure 2, plate II), are vestiges of an archedictyon which was presumably present in the more primitive or ancestral Brodiidae.

Since an archedictyon has not previously been observed in the Megasecoptera, we need to consider the question of whether the Brodiidae are Megasecoptera or Palaeodictyoptera. As noted previously, Handlirsch originally placed Brodia in the Palaeodictyoptera and Bolton (192I) persisted in this view. All other students of Palaeozoic insects have placed them in the Megasecoptera or in the Diaphanopterodea. The basic difficulty is that the more we know about the Megasecoptera the more they resemble the Palaeodictyoptera, at least in wing structure (Carpenter, 1963). It may well turn out that we are really dealing with a single order. However,

\section{Explanation of Plate 13}

Eubrodia dabasinskasi, n. sp. Photograph of middle part of wing (holotype), archedictyon (right side) and longer, irregular cross veins (left side) (times 9). 

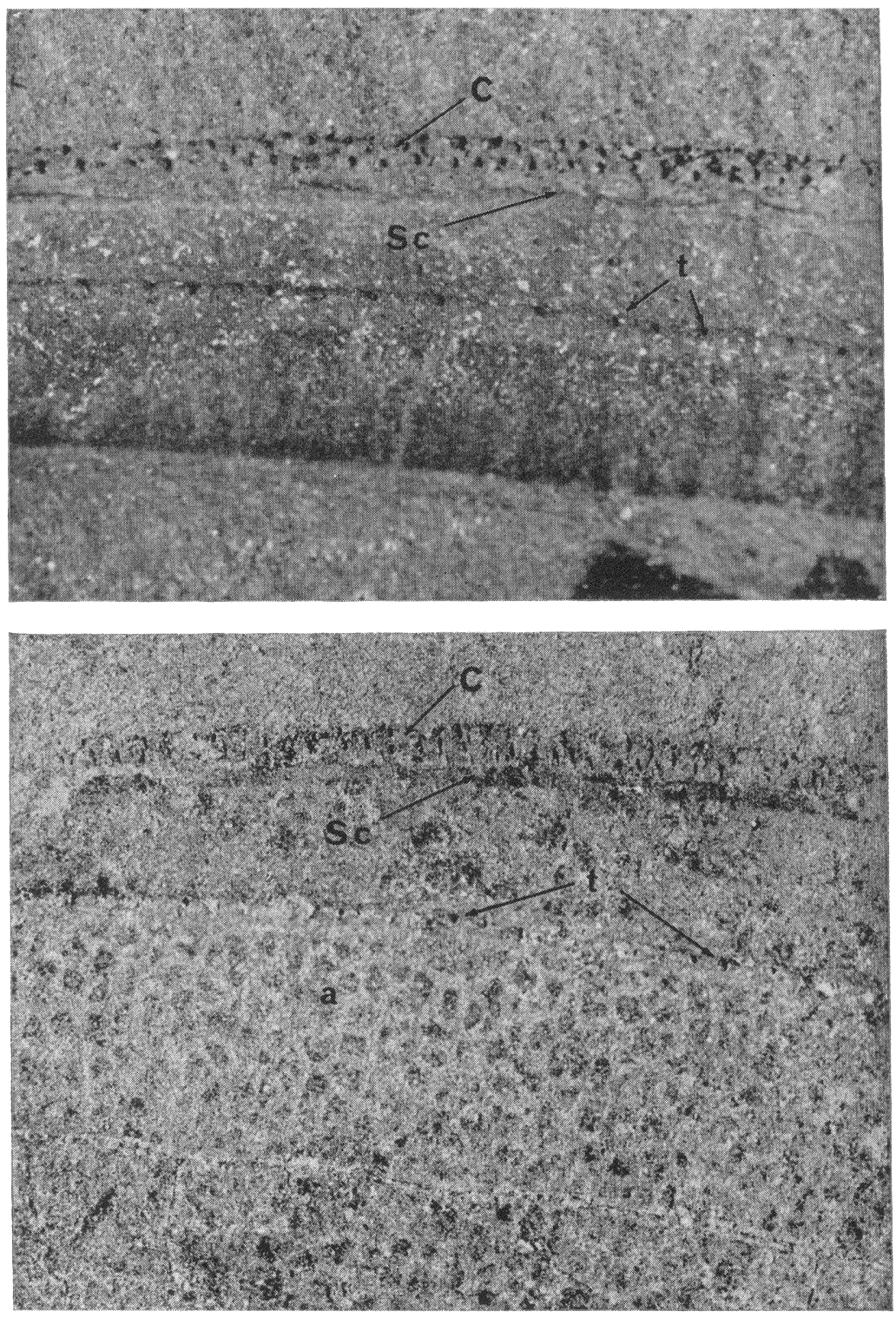

\section{Carpenter - Carboniferous Insects}


we do not know enough about the body structure of the Megasecoptera to permit us to reach a conclusion on the relationship between these two orders. We do not know, for example, whether or not they possessed the prominent beak, now recognized as characteristic of the Palaeodictyoptera. None of the Megasecoptera preserved show a beak but this evidence is negative; the structure of their mouthparts is not actually known. For the present, therefore, it seems advisable to continue to recognize these orders as distinct. The Brodiidae, on the basis of wings, could belong to either of these orders but the evidence is perhaps slightly in favor of the Megasecoptera. At any rate, it seems advisable in the absence of more positive evidence to continue to place the Brodiidae in that order, with the hope that some fortunate collector (perhaps Walter Dabasinskas) will find us a complete specimen of the Brodiidae.

\section{INSECTA INCERTAE SEDIS Family Sypharopteridae Handlirsch \\ Sypharoptera pneuma Handlirsch Text-fig. 5}

Sypharoptera pneuma Handlirsch, 1911, p. 372, fig. 55 (Order Sypharopteroidea) ; Handlirsch, 1921, p. 144, fig. 74; Martynov, 1938, p. 65, fig. 33 ; Rohdendorf, 1962, p. 69, figs. 106a, b (Order Diaphanopterodea, Suborder Protodiaphanopterodea); Laurentiaux, 1953, p. 426 (Sypharopterodea).

The specimen on which this species was based consists of four wings and part of the thorax and abdomen, the wings being directed backwards, obliquely along the abodmen. Since Handlirsch was unable to assign this fossil to any known order, extinct or Recent, he established a new one for it, the Sypharopteroidea, which he thought represented an extinct off-shoot of the Palaeodictyoptera, with possible relationship to the Megasecoptera. In r92 I he published a restored figure of the complete insect, showing the details of the head (including antennae and eyes) and legs, although none of these were

\section{Explanation of Plate 14}

Top figure, Brodia priscotincta Scudder. Photograph of part of wing in pterostigmal area (times 13); specimen in Scudder Collection, M.C.Z.

Bottom figure, Eubrodia dabasinskasi, n. sp. Photograph of part of wing in pterostigmal area (times 13), holotype.

Explanation of lettering: $C$, costa; Sc, subcosta; $t$, setal bases on $R 1$; a, archedictyon of Eubrodia. The costa shows the prominent setae that form the serrations. 
preserved in the single specimen known. Martynov (1938) faced with the problem of placing the insect in either his Palaeoptera or Neoptera, came to the conclusion that Sypharoptera was palaeopterous, assuming the flexed position of the wings as due to abnormal positioning at the time of preservation in the fossil state. He was also of the opinion that Sypharoptera was more similar to the Spilapteridae (Palaeodictyoptera) than to the Megasecoptera. Laurentiaux (1953) accepted this view but Rohdendorf (1962) placed Sypharoptera in the palaeopterous Order Diaphanopterodea, regarding the flexed wings as being in normal position.

Recently, through the kindness of the authorities at the Peabody Museum at Yale University, I have had the opportunity of studying this puzzling fossil. Since my interpretation differs from that of previous workers, I include here a new formal description of it and a discussion of its probable relationships.

The specimen is a small one, the fore wing of the type being Io $\mathrm{mm}$. long. Although the fore and hind wings are overlapped on each side of the abdomen, their venational pattern has been worked out without too much difficulty. ${ }^{6}$ The results of my efforts to untangle the veins are shown in text-figure 5 , which differs only slightly from that of Handlirsch (I9II): in both wings, in my opinion, $M$ arises from $\mathrm{CuA}$, and not as an independent vein from the base of the wing, as shown by Handlirsch. This origin of $M$ can be demonstrated in the fossil by the use of ammonium chloride and also by wetting the specimen with alcohol or water.

The subcosta terminates at about mid-wing, apparently on the costal margin; $\mathrm{RI}_{\mathrm{I}}$, which is strongly convex, is close to and about parallel to the anterior margin for most of its length; there are several oblique veinlets between $\mathrm{RI}_{\mathrm{I}}$ and the costa; $\mathrm{Rr}$, which is clearly concave, arises from $\mathrm{R}$ well before mid-wing and is directed away from $\mathrm{R}_{\mathrm{I}}$ distally, giving rise to four or five pectinate branches; the wide space between Rs and RI distally has several long, oblique veinlets; $\mathrm{M}$, as noted, arises from $\mathrm{CuA}$ near the wing base, slightly before the origin of Rs; this is a simple vein without branches and it is neutral in its topography, neither convex nor concave, and is here designated as $\mathrm{M}$; two branches of $\mathrm{Cu}$ are preserved in the fossil;

\footnotetext{
${ }^{6}$ This was done by the aid of photographic enlargements of the wings. The two sets of veins (those of each overlapped wing) were traced with inks of different colors, following the precise connections or deviations of each vein. Eventually the veins of each color were traced on separate sheets of thin paper.
} 

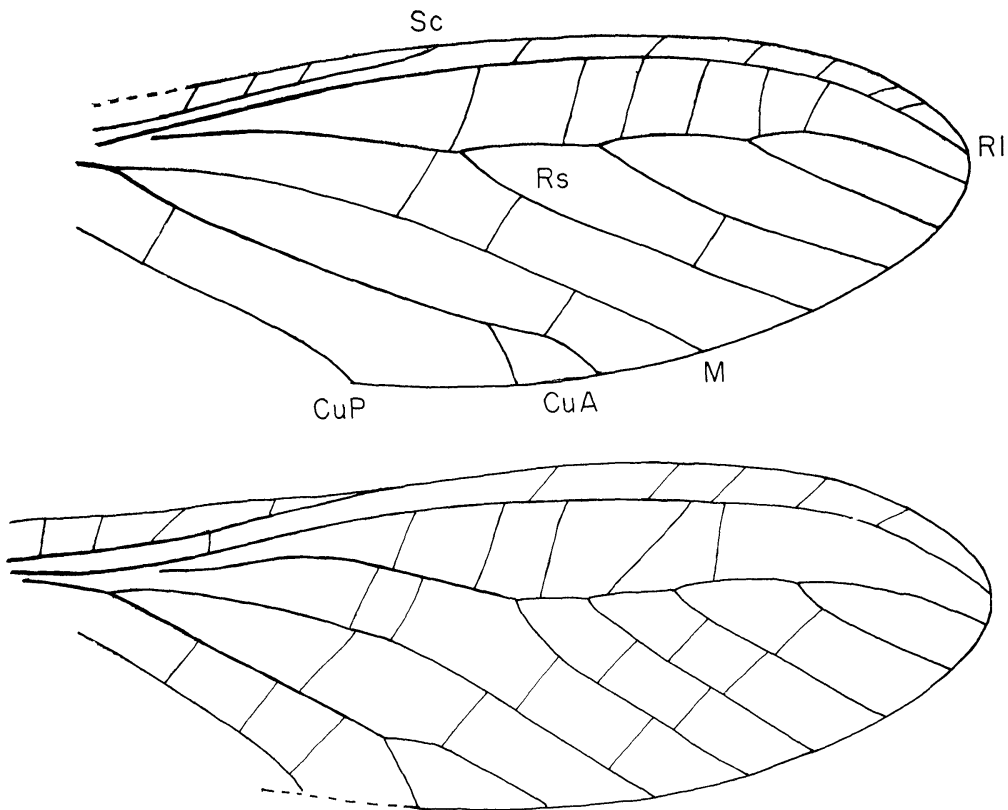

Text-fig. 5. Sypharoptera pneuma Handlirsch. Drawing of wings, based on holotype, Peabody Museum, Yale University. CuA is strongly convex; $M$ is neutral.

$\mathrm{CuA}$, which is strongly convex, gives rise to $\mathrm{M}$ and also to a short distal fork; $\mathrm{CuP}$ is concave and unbranched. The anal region is not preserved in either fore or hind wing.

Very little of the body structures are actually visible in the fossil. Handlirsch's figure (I9II) shows some details which I am unable to discern in the specimen, such as the subdivisions of the meso- and metathorax and the complete segmentation of the abdomen. At the end of the latter there are two very short cerci, consisting of two or possibly three segments; these are close together and were apparently interpreted by Handlirsch as forming a short ovipositor; these appendages are very small, only one-half millimeter in length, but the segmentation can distinctly be seen.

The venational pattern is the same in the fore and hind wings of Sypharoptera, at least in those parts of the wings which are preserved; the presence of an additional branch on Rs in one wing must be an individual wing variation, for it does not exist in the other hind wing of the specimen. The costal area of what appears to be 
the fore wing seems, curiously enough, to be somewhat more narrow than that of the hind wing but no other differences are apparent. The most striking feature of the wings is the presence of a single media, which is unbranched and which is neutral in its position. This would seem to me, without any question, to eliminate $S y p h a r o p-$ tera entirely from the Palaeoptera, which retain the convexity or concavity of the branches of $M$ to a very marked degree. On the other hand, this condition of $M$ is one which occurs in various groups of the Neoptera; and, of course, the position of the wings is neopterous. What is not known, unfortunately, is whether or not the hind wing possessed an expanded or enlarged anal area. In the hind wing of the fossil (and in the fore wing also for that matter) the anal area is completelv missing. It seems to me, therefore, that the bulk of the evidence, such as it is, points to the conclusion that Sypharoptera is not palaeopterous as it was treated by Martynov, Rohdendorf and Laurentiaux, but neopterous.

Within the great group of neopterous orders, the position of Sypharoptera is not at all clear on the basis of its venation; and the very short cerci are no real help. It seems to me, therefore, that the family Sypharopteridae should be placed in the category of the Insecta Incertae Sedis. Handlirsch's policy of erecting new orders for fragmentary fossils which he could not fit into known groups has no justification. He indicated that he was establishing orders "provisionally" but the meaning of that term is not clear, since all taxonomy is provisional, in the sense that changes may be made by subsequent investigators. The main disadvantage of the procedure followed by Handlirsch is that many meaningless, ordinal names are introduced into the literature, thus confusing the concept of the really extinct and valid orders. Until something is known of the body structure, including the mouth-parts, and the differences in the fore and hind wings, I consider it useless to establish separate orders for fossils. Accordingly, I am placing Sypharoptera in the category of Insecta Incertae Sedis; the name Sypharopterodea (or Sypharopteroidea as originally used by $\mathrm{Handlirsch)}$ remains associated with this insect as the nomen of a higher category, the nature of which will be determined after specimens have been found that provide enough information for definite conclusions.

Bolton, H.

\section{REFERENCES}

1917. On Blattoid and Other Insect Remains from the South Staffordshire Coalfield. Proc. Birm. Nat. Hist. Soc. 14: 100-106. 
1921. A Monograph of the Fossil Insects of the British Coal Measures. Lond. Palaeont. Soc., Pt. I.

Borre, A. P.

1875. Complément de la note sur des empreintes d'insectes fossiles. C. R. Soc. Ent. Belg. (2) 13: 7-11.

Brongniart, C.

1893. Recherches pour servir á l'histoire des insectes fossiles des temps primaires. St. Etienne. 493 pp.

Carpenter, F. M.

1947. Lower Permian Insects from Oklahoma. Part 1. Introduction and the Orders Megasecoptera, Protodonata, and Odonata. Proc. Amer. Acad. Arts and Sci. 76: 25-54.

1963. A Megasecopteron from Upper Carboniferous Strata in Spain. Psyche, 70 (1) : 44-49.

1964. Studies on North American Carboniferous Insects. 3. A Spilapterid from the Vicinity of Mazon Creek, Illinois (Palaeodictyoptera). Psyche 71(3): 117-124.

Handlirsch, A.

1906. Die fossilen Insekten. Leipzig.

1911. New Palaeozoic Insects from the Vicinity of Mazon Creek, Illinois. Amer. Journ. Sci. 31: 297-326, 353-377.

1919. Revision der Palaeozoischen Insekten, Denkschr. Akad. Wissenschaften Wien. Math. Naturw. Klasse 96: 511-592.

1921. Palaeontologie, in Schröder, Handbuch der Entomologie, 3 : 117306.

Keller, G.

1935. Ein neuer Palaeodictyopteron-Fund aus den Fettkohlenschichten (Westfal A) des Ruhrgebietes. Glückauf 71: 474-477.

KuKalová, J.

1959. Breyeria barborae n. sp. (Insecta, Palaeodictyoptera) of Upper Silesian Coal Basin (Westphalian). Vestnik UUG, 34: 310-313.

LAmeEre, A.

1917. Sur les insectes houillers de Commentry. Bull. Soc. Zool. Fr. 42: 27-37.

1917. Revision sommaire des insectes fossiles du Stephanien de Commentry. Bull. Mus. Paris. 23: 141-200.

LAURENTiaux, D.

1949. Un insecte nouveau (Breyeriidae) du terrain houiller du Pas-deCalais. Ann. Soc. geol. Nord, 69: 47-54.

1953. Classe des Insectes, in Piveteau, Traité de Paléontologie, 397-527.

LaURentiaux D. AND LaURentiauX-Vieira

1963. Nouvelle récolte d'un Breyeriide (Insecte paléodictyoptère) dans le Westphalien du Nord de la France. Ann. Soc. geol. Nord. 82: 173-178.

1964. Diagramme ptéronologique du genre westphalien Breyeria De Borre (Insectes Paléodictyoptères). C. R. Acad. Sc. Paris 258: 1282-1284. 
Martynov, A. V.

1938. Etudes sur l'histoire geologique et de phylogenie des ordres des insectes (Pterygota) le partie. Paleoptera et Neoptera (Polyneoptera). Trav. Inst. Paléont. Acad. Sci. U.R.S.S. 7: 1-150.

Meunier, F.

1910. Nouveaux Paléodictyoptères du Houiller de Commentry. Bull. Mus. Hist. Nat. 16: 233-237.

1912. Nouvelles recherches sur quelques insectes du terrain houiller de Commentry. 2nd part. Ann. Paleont. Paris 7: 1-19.

ROHDENDORF, et al.

1962. Principles of Palaeontology. (Osnovy). Akad. Nauk. SSSR, Moscow. $535 \mathrm{pp}$.

SCUDDER, S. H.

1881. Two New British Carboniferous Insects, with Remarks on those already known. Geol. Mag. 8: 293-300.

1883. The Carboniferous hexapod insects of Great Britain. Mem. Bost. Soc. Nat. Hist. 3 : 213-224.

1885. in Zittel, Handbuch der Palaeontologie, 747-831. 

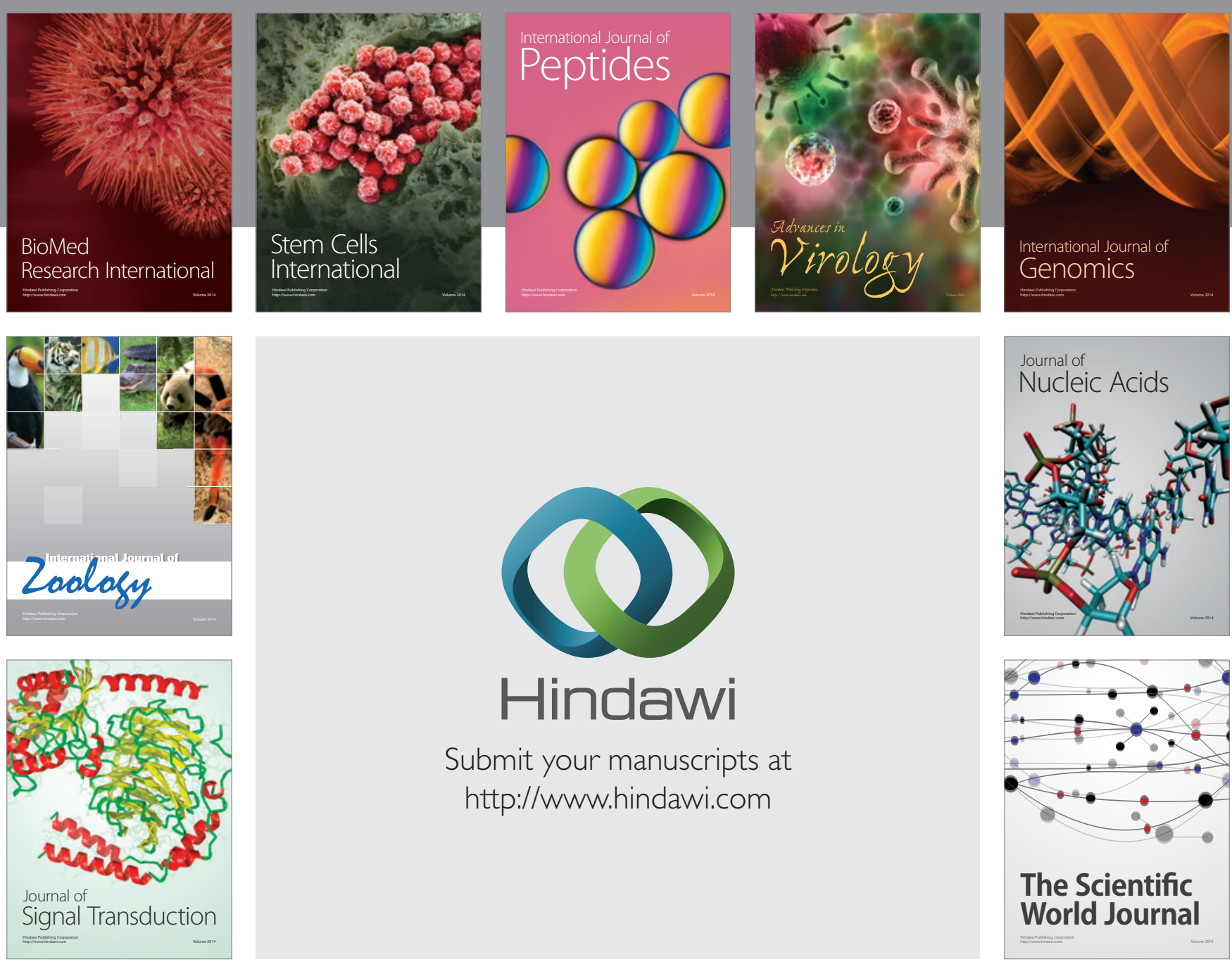

Submit your manuscripts at

http://www.hindawi.com
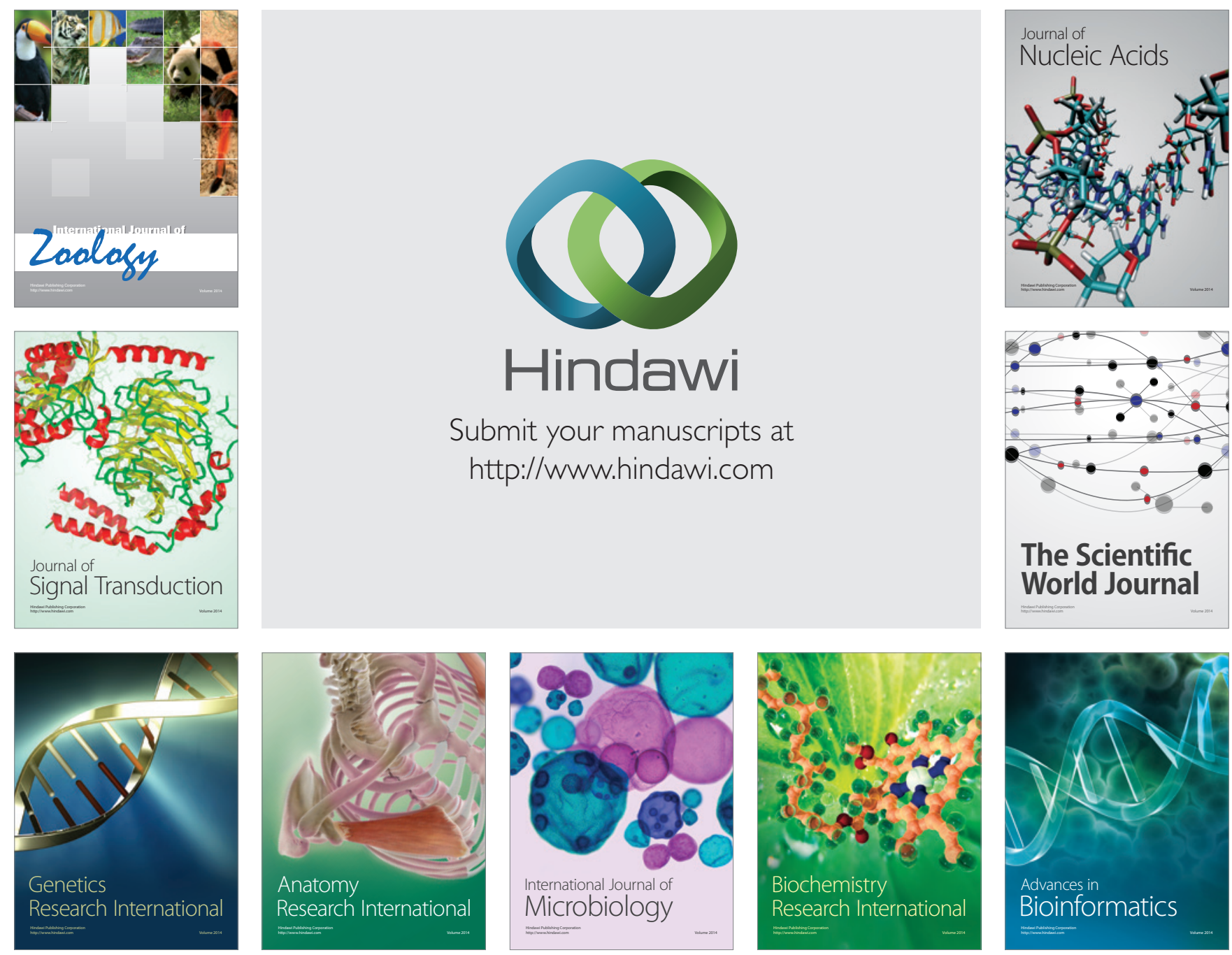

The Scientific World Journal
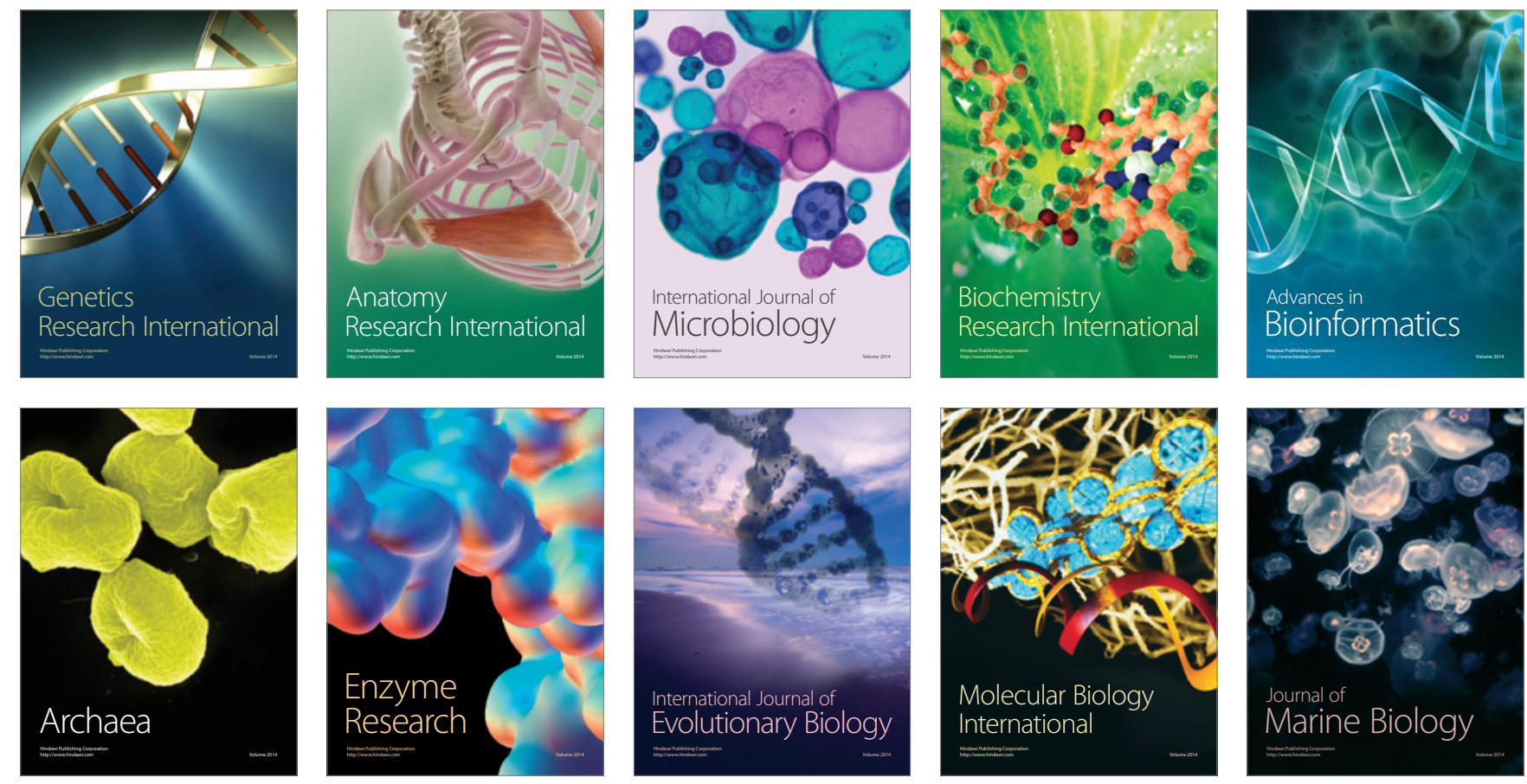